\title{
Analysis of muscle mobilization pattems and stop position of stones during sweeping each section of curling hog to hog
}

\author{
Young-il Kwon ${ }^{1}$, Tae-whan $\mathrm{Kim}^{2 *}$, \& Sang-hyup $\mathrm{Choi}^{3}$ \\ ${ }^{1}$ Uijeongbu Institution Public Corporation, ${ }^{2}$ Korea Institute of Sport Science $\&{ }^{3}$ Center for Sport Science in Jeju
}

\begin{abstract}
[Purpose] This is to provide essential data for training necessary for sweeping through the analysis of muscle activity generated at this time and how much sweeping and what trajectory moves the stone when the movement of the stone is controlled through sweeping. [Methods] To check and record the distance between the stones by checking the stop position of the stone made by sweeping each section, the length (progress distance) and width (progress direction) were recorded using a reference table and a record preparation table. With the EMG attached, a total of 60 sweeps were made 20 times each from the beginning of the section to the end of the section. Sweeping subjects were asked to sweep as much as possible under the same conditions in all three sections. [Results] As a result of the study, the muscle mobilization patterns of the 1st and 2nd sections of the stone with the faster speed and the 3rd section with the stone's slower speed appeared differently. It was confirmed that the sweeping motion of curling is a motion that is used evenly among the muscles of the upper extremity, and it can be verified that it is a suitable item for the development of upper body muscles. Also, the right deltoid's muscle activity rate during push and the right triceps brachii during pull was high. [Conclusions] Each section of the stone's sweeping effect is an exercise that has many variables, such as changes in atmospheric temperature and humidity, changes in ice temperature, temperature-size-number of pebbles, and the edge state-resilience of stones, etc. It is judged that experience can cope with these variables and requires training.
\end{abstract}

Key words: Sweeping, EMG, Curling stone, Hog to hog

\section{서 론}

컬링 경기에서는 팀워크와 더불어 작전수행 능력, 각 선 수의 기술능력(샷 능력, 스위핑 능력, 판단 능력 등)을 큰 요 소로 꼽을 수 있는데 그중 스위핑은 선수들의 샷 성공률을 높여 주고 샷이 보다 정확하게 목표에 도달 할 수 있도록 조 절해 주는 중요한 기술 중 하나이다(Bradley, 2009).

논문 투고일 : 2020. 12. 30.

논문 수정일 : 2021. 02. 08.

게재 확정일 : 2021. 03. 22.

* 교신저자 : 김태완(burumi@kspo.or.kr)
컬링은 투구되는 스톤을 회전시켜 회전하는 힘과 아 이스 표면의 마찰력에 의해 스톤의 진행거리와 진행방향 이 바뀌어 지는 특징을 가지고 있다. 이러한 변화는 환경 의 영향으로 그 크기와 성질이 바뀌어 질 수 있으며, 얼 음(ice)의 상태와 실내의 온도, 습도, 스톤의 엣지 상태, 선수들의 스위핑 등의 영향으로 진행방향과 스톤의 속도 가 달라진다. 여기에 환경적이 요인 외에 큰 영향을 미치 는 것이 선수들의 스위핑(sweeping)이다.

스위핑이란 스톤이 진행하는 방향 또는 진행하고자 하는 방향 쪽으로 브러쉬를 이용해 아이스 표면에 마찰을 주어서 마찰계수를 줄여 스톤이 그 방향으로 더욱 미끄러지게 하는 
것이다. 이 때 스위핑으로 변화 되는 것이 스톤의 진행거리 와 진행방향이다. 스위핑을 함으로써 더 멀리 나아 갈 수 있 게 하는 것이 목표이고 또 하나는 스톤의 회전(curl)으로 인해 큰 궤적으로 휘어져 들어가는 것을 스위핑을 통하 여 컨트롤 하는 것이 다른 하나의 목표이다. 따라서 컬링 경기에서의 스위핑은 매우 중요한 역할을 하지만 기존 대부분의 컬링관련 연구들은 컬링의 딜리버리에 관련한 운동학적 및 운동역학적 분석 연구(Kim, Kim, \& Kim, 2004; Kim, \& Cho, 2005; Lee, 2005; Kim, \& Yoo, 2006; Yoo, 2007, 2009; Kivi \& Auld, 2012 ; Yoo, Kim, \& Park, 2012; Kim et al., 2014)가 거의 전부 였으며, 브러쉬와 얼음의 상관관계에 관련한 연구 (Marmo, Farrow, Buckingham, \& Blackford, 2006, Buckingham, Marmo, \& Blackford, 2006; Hitoshi et al., 2008; Hitoshi et al., 2012)는 당시 첨단 센서에 해당하는 소형 가속도 센서와 스트레인 게이지를 브 러쉬에 장착하여 브러쉬의 물리량의 변화를 측정하는 연구 와 소형 실험용 베드(Test bed)를 제작하여 브러쉬의 움직 임에 따른 얼음의 온도 변화를 측정하는 연구를 수행하였다 (Lee, Kim, Kil, \& Choi, 2017). 그러나 이러한 연구에서 사용된 소형 실험용 그 크기에서 연구되어 현장성 연구에 적 용하기엔 무리가 있다. 또한, 스위핑 시 나타나는 스톤의 이 동거리 및 스위핑 속도를 분석한 연구에서는 스위핑 속도가 빠를수록 스톤의 이동거리가 커지는 것을 알 수 있었다 (Kim et al., 2018). 하지만, 본 연구에서 실제 컬링장에서 같은 힘과 방향으로 던져진 스톤들을 통해 스위핑 구간을 설 정하여 스톤의 속도가 가장 빠른 초기와 중간빠르기로 접어 드는 중기 그리고 느리게 변화되는 말기에 각 스위핑을 실시 하여 스톤이 멈춰지는 최종 위치를 파악해 구간별 스위핑을 통한 스톤의 최종 위치 변화와 이때 발생되는 근 활성도 분 석이 필요할 것으로 판단되어 본 연구를 착수하게 되었다. 스위핑 시 나타나는 근 활성도 분석을 한 선행 연구에서는 스위핑 시 가장 크게 나타나는 근 활성도는 오른쪽 삼각근과 왼쪽 복직근, 오른쪽 상완삼두근, 왼쪽 척측수근신근이었다 (Kim et al., 2021). 그러나 호그에서 호그 사이의 구간 별 스위핑 방법이 다를 것이고 그에 따른 근 활성도 패턴도 다 를 것이라고 사료된다. 따라서, 본 연구에서의 근 활성도 측 정은 스톤의 이동이 스위핑을 통하여 컨트롤 될 때 어떤 타 이밍에 얼마만큼의 스위핑이 어떤 궤적을 만드는지 등과 같 은 스위핑에 필요한 기초적 훈련 자료를 제공하는데 있다.

\section{연구방법}

\section{연구대상}

본 연구의 대상은 U지역 중·고등부 선수남중 5명, 남고 5 명 총 10 명을 대상으로 하였으며 고등부 선수는 나이 $17.6 \pm 0.5$ 세, 신장 $169.2 \pm 5.2 \mathrm{~cm}$, 체중 $61.8 \pm 7.9 \mathrm{~kg}$, 경

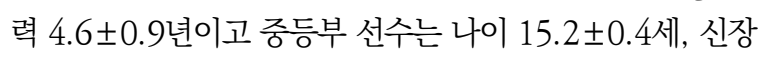
$164.4 \pm 3.9 \mathrm{~cm}$, 체중 $50.2 \pm 4.9 \mathrm{~kg}$, 경력 $2 \pm 0$ 년이다. 모 든 연구 대상자는 사전에 연구 참여 동의서에 서명을 하고 실험에 참가하였다.

\section{실험장비}

본 연구에서 사용된 실험 장비는 〈Table 1〉과 같다.

Table 1. Measurement equipments

\begin{tabular}{cccc}
\hline \hline \multirow{2}{*}{ Division } & $\begin{array}{c}\text { Measurement } \\
\text { and Aanalysis }\end{array}$ & $\begin{array}{c}\text { Experimental } \\
\text { Tools }\end{array}$ & Company \\
\hline Hardware & $\begin{array}{c}\text { Motion } \\
\text { Photography }\end{array}$ & $\begin{array}{c}\text { Digital Video } \\
\text { Camera }\end{array}$ & Sony \\
\cline { 2 - 4 } & $\begin{array}{c}\text { EMG } \\
\text { Mearsurment }\end{array}$ & DTS System & Noraxon \\
\hline Software & EMG Analysis & $\begin{array}{c}\text { MyoResearch } \\
\text { XP Program }\end{array}$ & Noraxon \\
\hline \hline
\end{tabular}

구간 분류 및 스톤의 진행 상황 등을 확인하기 위하여 호 그라인 시작과 끝 지점까지의 스위핑 동작을 모두확인할 수 있도록 카메라를 위치시킨 후, Telemyo DTS(Noraxon, USA)을 각 근육 부위에 부착하여 각 구간 별 스위핑 차이에 따른 근육의 발현의 정도를 측정하였다. 이때 자료 샘플링 주파수는 $1,500 \mathrm{~Hz}$ 로 설정하였으며, 동작 수행 시 얻어진 근 육의 파형분석 프로그램으로 MyoResearch XP 프로그램 을 이용하여 분석하였다(Figure 1).
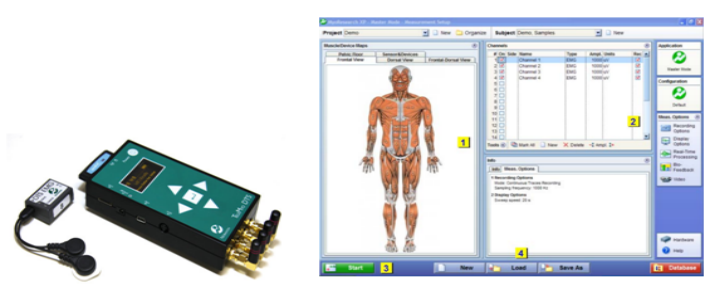

Fig. 1. Telemyo DTS \& MyoResearch XP 


\section{실험방법 및 절차}

본 연구에서 한 선수가 일정한 웨이트, 라인, 턴으로(같은 조건으로) 딜리버리를 할 때 스위핑 대상 선수가 호그에서 호그사이를 구간(section)별로 나누어 같은 프레스와 속도 그리고 같은 횟수로 스위핑을 하게 한 후 구간 별 근 동원양 상을 측정하였다. 스위핑 구간 설정은 〈Figure 2〉와 같이 호그 투 호그 구간을 3 등분으로 나누어 분석하였으며, 그 기 준은 처음 $1 / 3$ 지점 $(7.3 \mathrm{~m})$ 을 1 구간, 두 번째 $1 / 3$ 지점 (14.6m)을 2구간, 마지막 $1 / 3$ 지점 $(21.9 \mathrm{~m})$ 을 3 구간으로 구분하여 측정하였다.

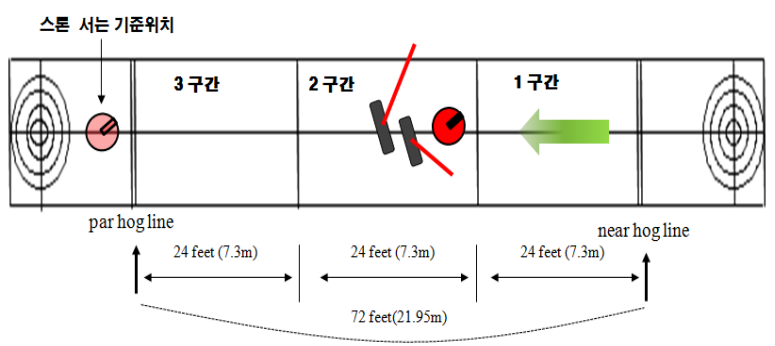

Fig. 2. Sweeping section setting

또한 구간을 시작하는 시점에서부터 끝나는 시점동안 각 20 번 씩 총 60 번 스위핑을 하게 하였다. 스위핑을 하는 대 상자가 세 구간 모두 같은 조건으로 최대한 스위핑을 할 수 있도록 요구하였다.

스위핑 방법은 브러쉬 패드의 각도는 30도의 각도에서 비스듬히 움직이며 스위핑의 간격은 가장 효율적이고 안정 적인 넓이인 스톤의 크기보다 양쪽으로 $5 \mathrm{~cm}$ 정도 나오게 유 도하였다.

스위핑 시 근전도 자료를 얻기 위해 상지의 좌우측 삼 각근(RDE, LDE: Deltoideus anterior), 상완이두근 (RBB, LBB : Biceps brachii), 상완삼두근(RTB, LTB : Triceps brachii), 광배근(RLD, LLD : Latissimus dorsi)), 대흥근(RPM, LPM : Pectoralis major), 복직 근(RRA, LRA : Rectus abdominis) 등 총 12 개의 근육 의 피부 표면 털을 제거한 후, 알코올로 세척하여 Bipolar 표면전극(dual electrode, Noraxon, USA; 전 근간 거리 : $1.5 \mathrm{~cm})$ 을 부착하였으며, 전극의 부착 위치 정 보는 SENIAM(Surface Electromyography for the Non-Invasive Assessment of Muscles)의 가이드라
인을 참조하여 각 근육의 위치를 선정하였다(Figure 3).

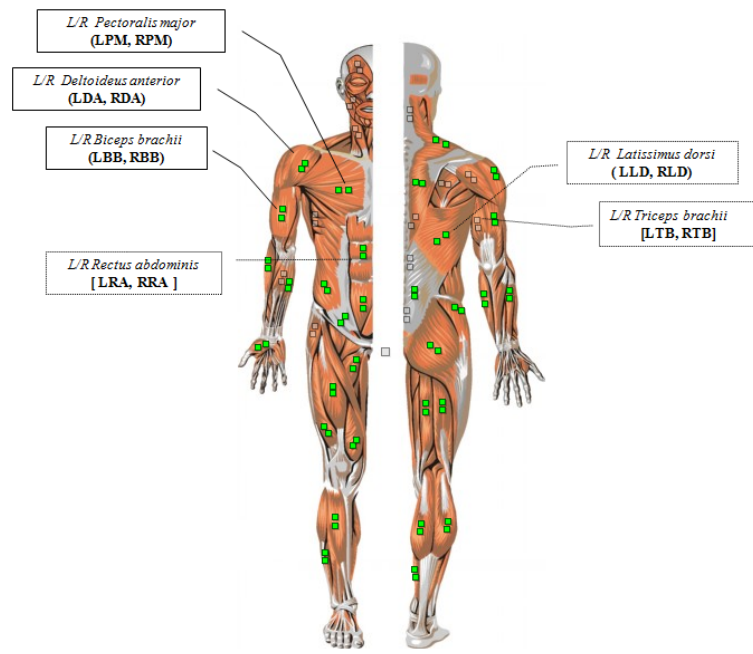

Fig. 3. Electrode attachment position

실제 근육의 활동을 측정하기 위하여 무선 근전도 시스템 (DTS Probe Transmitter, Noraxon USA, Inc, sample rates 1500 fixed, input impedance $>100 \mathrm{M} \Omega$, CMRR $>100 \mathrm{~dB}$, Input Range $+/-3.5 \mathrm{~V}$, center to center distance $=15 \mathrm{~mm})$ 을 사용하였다. 이때 동작의 이벤트 및 국 면을 정하기 위해 디지털 캠코더를 사용하여 수행하는 모습 을 촬영하였다. 캠코더 영상을 근 활성도와 sync를 맞추기 위해 noraxon 프로그램 내 measurement setup에서 캠 코더를 input하여 동조화했다. 또한, 이벤트와 국면 구분을 noraxon 프로그램 marker로 설정하였다.

측정된 원 자료(raw data)는 연구대상자의 움직임과 실 험 환경적인 요인으로 인한 노이즈(noise)를 제거하기 위하 여 FIR high pass filter 방법에 의한 차단 주파수(cut-off frequency)를 $6 \mathrm{~Hz}$ 로 처리 하였으며, 이후 full wave rectification을 적용한 후 RMS $50 \mathrm{~ms}$ 로 정량화하여 분석 하였다. RVC(reference voluntary contraction)는 1 구 간부터 3구간까지 총 60 회의 스위핑 시 각 구간 별최대 값 (peak value) 분석으로 기준을 설정하였다.

스톤의 멈춘 위치 확인방법은 각 구간별 스위핑을 통 해 이루어진 스톤의 멈춘 위치를 확인하여 스톤간의 거 리를 길이(진행거리)와 너비(진행방향)를 〈Figure 4〉를 참고로 체크하여 기록하였다. 


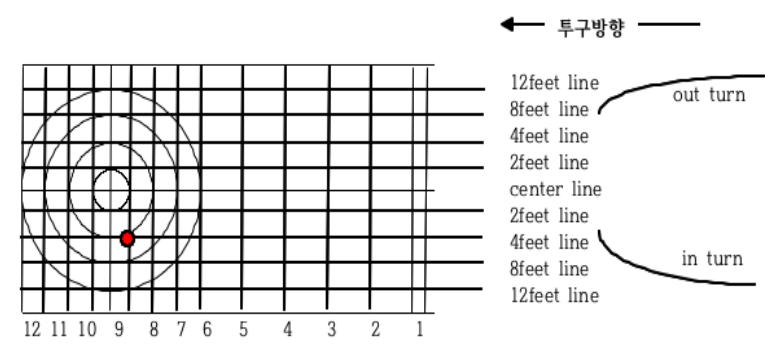

Fig. 4. Stone's Stop Position Selection Criteria Table

\section{자료 처리}

본 연구에서 데이터 분석의 주요한 목적은 구간별 스위핑 시 상지의 근 동원 양상 간 평균값(mean)을 구간별로 비교 검증하는 것이다. 따라서 본 연구의 실험설계는 스위핑을 구간별로 20회 씩 반복 측정하였으며, 모든 변수는 MS Office Excel 2007 프로그램을 사용하여 평균과 표준편차 를 구한 후 비교하였다. 또한 각 섹션 당 스위핑 당기기와 밀 기 동작 간 각 근육 부위의 동원 크기의 차이를 알아보기 위 해 대응표본 t-검정을 실시하였다.

\section{연구결과}

컬링 호구 투 호구 각 구간 스위핑 시 스톤의 서는 위치와 상지의 근 동원양상을 알아보기 위해 측정된 평균 근전도를 비교 분석한 결과 다음과 같다.

\section{구간별 스위핑 당기기 시 평균 근전도}

컬링 스위핑 당기기 동작 시의 구간별 20회씩 실시하 여 측정된 근전도 자료를 \%RVC로 분석한 결과는
〈Table 2〉와 같다. 컬링 스위핑 당기기 시 구간별 근활 성도에서 1 구간에서는 왼쪽 광배근(57.7\%), 오른쪽 복 직근(55.3\%), 오른쪽 상완삼두근(53.7\%)의 비율 순으 로 많이 쓰이는 것을 알 수 있으며, 2구간에서는 오른쪽 상완이두근(57\%), 오른쪽 광배근(54.7\%), 오른쪽 복직 근(54.3\%)의 순서로, 3 구간에서는 왼쪽 삼각근(86.6\%) 로 현격하게 많이 사용되는 것을 확인되었으며, 그다음 순으로 오른쪽 상완이두근(70\%), 왼쪽 상완이두근 (63.6\%)이 많이 사용되는 것으로 나타났다.

\section{구간별 스위핑 밀기 시 평균 근전도}

컬링 스위핑 밀기 동작 시의 구간별 20회씩 실시하여 측 정된 근전도 자료를 다시 \%RVC로 분석한 결과는 〈Table $3>$ 과 같다. 컬링 스위핑 밀기 시 구간별 근활성도에서 1 구간 에서는 오른쪽 상완이두근(57.5\%), 오른쪽 대흥근(56.6\%), 왼쪽 상완이두근(56.5\%)의 비율 순으로 많이 쓰이는 것을 알 수 있고, 2구간에서는 오른쪽 상완이두근(57.4\%), 왼쪽 광배근(55.4\%), 오른쪽 대흥근(54.8\%)순으로, 3구간에서는 오른쪽 상완삼두근(61.7\%), 왼쪽 복직근(61.5\%), 왼쪽 광배 근(57.2\%)순으로 많이 사용된 것으로 나타났다.

\section{구간별 스위핑 당기기 시 근 동원 순서}

컬링 스위핑 당기기 동작 시의 근 동원 순서를 알아보기 위해 전체 근육을 합한 다음 각 근육별로 나누어 백분율로 제시하였다. 그 결과는 〈Table 4>와 같다. 1 구간에서의 근 동원순서는 왼쪽 광배근 > 오른쪽 상완삼두근 > 오른쪽 복 직근 > 오른쪽 상완이두근 > 오른쪽 대흉근 > 오른쪽 광배근 $>$ 왼쪽 대흉근 > 왼쪽 상완 삼두근 > 왼쪽 복직근 > 왼쪽 상

Table 2. Average EMG results for each section during the pulling sweeping period (\%RVC)

\begin{tabular}{|c|c|c|c|c|c|c|c|c|c|c|c|c|c|}
\hline & & $\mathrm{RDE}$ & LDE & RPM & LPM & RBB & LBB & RLD & LLD & RRA & LRA & RTB & LTB \\
\hline \multirow{2}{*}{ Section 1} & M & 41.8 & 36.2 & 51.1 & 48.8 & 51.7 & 46.5 & 50.8 & 57.7 & 53.7 & 46.8 & 55.3 & 48.2 \\
\hline & SD & 7.1 & 7.1 & 6.2 & 8.7 & 8.3 & 8.8 & 7.9 & 8.6 & 9.8 & 9.1 & 8.0 & 9.4 \\
\hline \multirow{2}{*}{ Section 2} & $\mathrm{M}$ & 42.4 & 38.1 & 50.2 & 53.6 & 57.0 & 47.7 & 54.7 & 52.7 & 54.3 & 51.4 & 52.3 & 44.5 \\
\hline & SD & 7.1 & 6.4 & 8.4 & 8.9 & 9.5 & 8.0 & 9.1 & 8.8 & 9.1 & 8.6 & 8.7 & 7.4 \\
\hline \multirow{2}{*}{ Section 3} & M & 41.2 & 86.6 & 58.0 & 45.2 & 70.0 & 63.6 & 54.7 & 53.8 & 55.1 & 45.9 & 54.3 & 63.0 \\
\hline & SD & 6.0 & 12.5 & 8.4 & 6.5 & 10.1 & 9.2 & 7.9 & 7.8 & 8.0 & 6.6 & 7.9 & 9.1 \\
\hline
\end{tabular}


완이두근 > 오른쪽 삼각근 > 왼쪽 삼각근 순으로 보통 오른 쪽 근육쓰임의 분포가 주로 앞쪽에 있는 것을 확인 할 수 있 고, 삼각근이 대체적으로 적게 사용되는 것을 알 수 있었다.

2 구간의 근동원순서는 오른쪽 상완이두근 > 오른쪽 광배 근 > 오른쪽 복직근 > 왼쪽 대흉근 > 왼쪽 광배근 > 오른쪽 상완삼두근 > 왼쪽 복직근 > 오른쪽 대흥근 > 왼쪽 상완이두 근 > 왼쪽 상완삼두근 > 오른쪽 삼각근 > 왼쪽 삼각근 순으 로 1 구간과는 다소 다른 근동원순서가 나타났지만 2 구간 역 시 삼각근의 근 비율이 대체적으로 많이 사용되지 않는 것으 로 확인되었다. 마지막 3구간은 왼쪽 삼각근 > 오른쪽 상완 이두근 > 왼쪽 상완이두근 > 왼쪽 상완삼두근 > 오른쪽 대흥 근 > 오른쪽 복직근 > 오른쪽 광배근 > 오른쪽 상완삼두근 > 왼쪽 광배근 > 왼쪽 복직근 > 왼쪽 대흥근 > 오른쪽 삼각
근 순으로 왼쪽 삼각근의 비율이 가장 높게 나타났으며, 오 른쪽 삼각근의 비율이 가장 적게 나타났다.

\section{구간별 스위핑 밀기 시 근 동원 순서}

컬링 스위핑 밀기 동작 시의 근 동원순서를 알아보기 위해 전체 근육을 합한 다음 각 근육별로 나누어 백분율 로 제시하였다. 그 결과는 〈Table 5〉와 같다. 밀기 동작 시 근동원순서로는 1 구간에서 오른쪽 상완이두근 > 오른 쪽 대흉근 > 왼쪽 상완이두근 > 오른쪽 복직근 > 오른쪽 삼각근 > 오른쪽 상완삼두근 > 왼쪽 광배근 > 오른쪽 광배 근 $>$ 왼쪽 삼각근 $>$ 왼쪽 삼완삼두근 $>$ 왼쪽 복직근 $>$ 왼쪽 대흉근 순으로 오른쪽 상완이두근과 대흥근이 높은 비율

Table 3. Average EMG results for each section during the pushing sweeping period (\%RVC)

\begin{tabular}{|c|c|c|c|c|c|c|c|c|c|c|c|c|c|}
\hline & & $\mathrm{RDE}$ & LDE & RPM & LPM & $\mathrm{RBB}$ & LBB & RLD & LLD & RRA & LRA & RTB & LTB \\
\hline \multirow{2}{*}{ Section 1} & M & 53.0 & 49.1 & 56.6 & 44.9 & 57.5 & 56.5 & 50.5 & 51.5 & 55.0 & 46.7 & 51.7 & 48.6 \\
\hline & SD & 8.5 & 7.9 & 9.1 & 7.2 & 9.2 & 9.1 & 8.1 & 8.3 & 8.8 & 7.5 & 8.3 & 7.8 \\
\hline \multirow{2}{*}{ Section 2} & M & 50.8 & 47.0 & 54.8 & 44.9 & 57.4 & 52.4 & 50.6 & 55.4 & 53.3 & 47.3 & 50.0 & 52.8 \\
\hline & SD & 8.2 & 7.6 & 8.9 & 7.3 & 9.3 & 8.5 & 8.2 & 9.0 & 8.6 & 7.7 & 8.1 & 8.6 \\
\hline \multirow{2}{*}{ Section 3} & M & 56.1 & 37.7 & 49.2 & 61.9 & 54.7 & 51.5 & 52.7 & 57.2 & 55.3 & 61.5 & 61.7 & 48.5 \\
\hline & SD & 8.7 & 5.8 & 7.6 & 9.6 & 8.4 & 7.9 & 8.1 & 8.8 & 8.5 & 9.5 & 9.5 & 7.5 \\
\hline
\end{tabular}

Table 4. Results of rank ratio by section during the pulling sweeping period (\%RVC)

\begin{tabular}{|c|c|c|c|c|c|c|c|c|c|c|c|c|c|}
\hline \multirow{2}{*}{ Section 1} & LLD & RTB & RRA & $\mathrm{RBB}$ & RPM & RLD & LPM & LTB & LRA & LBB & $\mathrm{RDE}$ & LDE & Total(\%) \\
\hline & 9.8 & 9.4 & 9.1 & 8.8 & 8.7 & 8.6 & 8.3 & 8.2 & 8.0 & 7.9 & 7.1 & 6.2 & 100.0 \\
\hline \multirow{2}{*}{ Section 2} & RBB & RLD & RRA & LPM & LLD & RTB & LRA & RPM & LBB & LTB & $\mathrm{RDE}$ & LDE & Total(\%) \\
\hline & 9.5 & 9.1 & 9.1 & 8.9 & 8.8 & 8.7 & 8.6 & 8.4 & 8.0 & 7.4 & 7.1 & 6.4 & 100.0 \\
\hline \multirow{2}{*}{ Section 3} & LDE & $\mathrm{RBB}$ & LBB & LTB & RPM & RRA & RLD & RTB & LLD & LRA & LPM & $\mathrm{RDE}$ & Total(\%) \\
\hline & 12.5 & 10.1 & 9.2 & 9.1 & 8.4 & 8.0 & 7.9 & 7.9 & 7.8 & 6.6 & 6.5 & 6.0 & 100.0 \\
\hline
\end{tabular}

Table 5. Results of rank ratio by section during the pushing sweeping period (\%RVC)

\begin{tabular}{|c|c|c|c|c|c|c|c|c|c|c|c|c|c|}
\hline \multirow{2}{*}{ Section 1} & $\mathrm{RBB}$ & RPM & LBB & RRA & $\mathrm{RDE}$ & RTB & LLD & RLD & LDE & LTB & LRA & LPM & Total(\%) \\
\hline & 9.3 & 9.1 & 9.1 & 8.8 & 8.5 & 8.3 & 8.3 & 8.1 & 7.9 & 7.8 & 7.5 & 7.2 & 100.0 \\
\hline \multirow{2}{*}{ Section 2} & RBB & LLD & RPM & RRA & LTB & LBB & $\mathrm{RDE}$ & RLD & RTB & LRA & LDE & LPM & Total(\%) \\
\hline & 9.3 & 9.0 & 8.9 & 8.6 & 8.6 & 8.5 & 8.2 & 8.2 & 8.1 & 7.7 & 7.6 & 7.3 & 100.0 \\
\hline \multirow{2}{*}{ Section 3} & LPM & RTB & LRA & LLD & $\mathrm{RDE}$ & RRA & RBB & RLD & LBB & RPM & LTB & LDE & Total(\%) \\
\hline & 9.6 & 9.5 & 9.5 & 8.8 & 8.7 & 8.5 & 8.4 & 8.1 & 7.9 & 7.6 & 7.5 & 5.8 & 100.0 \\
\hline
\end{tabular}


로 근동원이 이루어지는 것으로 나타났다. 2 구간 역시 오 른쪽 상완이두근 > 왼쪽 광배근 > 오른쪽 대흉근 > 오른쪽 복직근 > 왼쪽 상완삼두근 > 왼쪽 상완이두근 > 오른쪽 삼 각근 $>$ 오른쪽 광배근 > 오른쪽 상완삼두근 > 왼쪽 복직근 $>$ 왼쪽 삼각근 > 왼쪽 대흉근 순으로 1 구간과 비슷한 근동 원양상을 보였다. 마지막 3구간에서는 왼쪽 대흥근 > 오 른쪽 상완삼두근 > 왼쪽 복직근 > 왼쪽 광배근 > 오른쪽 삼각근 > 오른쪽 복직근 > 오른쪽 상완이두근 > 오른쪽 광 배근 > 왼쪽 상완이두근 > 오른쪽 대흥근 > 왼쪽 상완삼두 근 > 왼쪽 삼각근순으로 근동원 비율이 형성이 되었는데 당기기 시 근원동원순서와는 정 반대로 왼쪽 삼각근이 제 일 적게 동원되는 것으로 나타났다.

\section{구간별 스위핑 당기기와 밀기 간 근 동원 차이}

\section{1) 구간 1(Section 1)}

Table 6. Mean comparison of EMG during sweeping pulling and pushing (section 1)

\begin{tabular}{|c|c|c|c|c|c|}
\hline \multicolumn{2}{|c|}{ Muscles(EMG) } & $\mathrm{M}$ & SD & $\mathrm{t}$ & $\mathrm{p}$ \\
\hline \multirow{4}{*}{$\mathrm{DE}$} & \multirow{2}{*}{$\mathrm{R}$} & 41.76 & 9.85 & \multirow{2}{*}{$-3.33^{* *}$} & \multirow{2}{*}{0.01} \\
\hline & & 52.97 & 5.63 & & \\
\hline & \multirow{2}{*}{$\mathrm{L}$} & 36.24 & 15.68 & \multirow{2}{*}{-1.31} & \multirow{2}{*}{0.22} \\
\hline & & 49.10 & 15.91 & & \\
\hline \multirow{4}{*}{ PM } & \multirow{2}{*}{$\mathrm{R}$} & 51.12 & 6.22 & \multirow{2}{*}{-1.45} & \multirow{2}{*}{0.18} \\
\hline & & 56.62 & 8.10 & & \\
\hline & \multirow{2}{*}{$\mathrm{L}$} & 48.77 & 12.04 & \multirow{2}{*}{0.60} & \multirow{2}{*}{0.56} \\
\hline & & 44.90 & 9.92 & & \\
\hline \multirow{4}{*}{ BB } & \multirow{2}{*}{$\mathrm{R}$} & 51.72 & 15.86 & \multirow{2}{*}{-0.78} & \multirow{2}{*}{0.45} \\
\hline & & 57.46 & 11.21 & & \\
\hline & \multirow{2}{*}{$\mathrm{L}$} & 46.53 & 9.93 & \multirow{2}{*}{-1.16} & \multirow{2}{*}{0.27} \\
\hline & & 56.47 & 22.32 & & \\
\hline \multirow{4}{*}{ LD } & \multirow{2}{*}{$\mathrm{R}$} & 50.76 & 6.86 & \multirow{2}{*}{0.08} & \multirow{2}{*}{0.94} \\
\hline & & 50.45 & 9.92 & & \\
\hline & \multirow{2}{*}{$\mathrm{L}$} & 57.70 & 13.98 & \multirow{2}{*}{0.88} & \multirow{2}{*}{0.40} \\
\hline & & 51.46 & 11.33 & & \\
\hline \multirow{4}{*}{ RA } & \multirow{2}{*}{$\mathrm{R}$} & 53.74 & 6.88 & \multirow{2}{*}{-0.26} & \multirow{2}{*}{0.80} \\
\hline & & 54.96 & 10.31 & & \\
\hline & \multirow{2}{*}{$\mathrm{L}$} & 46.84 & 12.95 & & \\
\hline & & 46.69 & 10.60 & 0.02 & 0.98 \\
\hline & & 55.33 & 5.94 & & \\
\hline $\mathrm{TP}$ & $\mathrm{R}$ & 51.72 & 7.57 & $2.41^{* *}$ & 0.04 \\
\hline ID & & 48.19 & 10.25 & & \\
\hline & $\mathrm{L}$ & 48.56 & 14.37 & -0.05 & 0.96 \\
\hline
\end{tabular}

구간 1 에서의 스위핑 당기기와 밀기 간 근 동원 평균이 유의한 차이를 보이는지 검증하고자 대응표본 t-검정을 실 시하였다. 그 결과 오른쪽 우측 삼각근과 우측 상완삼두근 에서 유의한 차이를 보이는 것으로 나타났다(각각 $\mathrm{t}=-3.33$, $\mathrm{p}<.01, \mathrm{t}=2.41, \mathrm{p}<.04)$. 평균 비교 결과, 우측 삼각근은 당 기기 시 $41.76 \% \mathrm{RVC}$, 밀기 시에는 $52.97 \% \mathrm{RVC}$ 를 나타내 밀기시 더 큰 근 동원 양상을 보였고, 우측 상완삼두근은 당 기기 시 55.33\%RVC, 밀기 시 51.72\%RVC를 나타내 당기 기 시 더 큰 근 동원 양상을 보였다(Table 6).

\section{2) 구간 2(Section 2)}

구간 2에서의 스위핑 당기기와 밀기 간 근 동원 평균의 유의한 차이 검증 결과, 우측 삼각근에서 유의한 차이를 보 였다 $(\mathrm{t}=-2.55, \mathrm{p}<.01)$. 평균 비교 결과는 당기기 시 42.42\%RVC, 밀기 시 50.79\%RVC를 나타내 밀기 시 더 큰 근 활성도를 나타냈다(Table 7).

Table 7. Mean comparison of EMG during sweeping pulling and pushing (section 2)

\begin{tabular}{|c|c|c|c|c|c|}
\hline \multicolumn{2}{|c|}{ Muscles(EMG) } & M & SD & $t$ & $p$ \\
\hline \multirow{4}{*}{$\mathrm{DE}$} & \multirow{2}{*}{$\mathrm{R}$} & 42.42 & 10.38 & \multirow{2}{*}{$-2.55^{* *}$} & \multirow{2}{*}{0.03} \\
\hline & & 50.79 & 5.06 & & \\
\hline & \multirow{2}{*}{$\mathrm{L}$} & 38.15 & 13.59 & \multirow{2}{*}{-0.95} & \multirow{2}{*}{0.37} \\
\hline & & 47.05 & 16.71 & & \\
\hline \multirow{4}{*}{ PM } & \multirow{2}{*}{$\mathrm{R}$} & 50.16 & 7.73 & \multirow{2}{*}{-1.04} & \multirow{2}{*}{0.33} \\
\hline & & 54.80 & 7.45 & & \\
\hline & \multirow{2}{*}{$\mathrm{L}$} & 53.58 & 13.01 & \multirow{2}{*}{1.19} & \multirow{2}{*}{0.26} \\
\hline & & 44.86 & 11.56 & & \\
\hline \multirow{4}{*}{$\mathrm{BB}$} & \multirow{2}{*}{$\mathrm{R}$} & 57.00 & 11.45 & \multirow{2}{*}{-0.07} & \multirow{2}{*}{0.95} \\
\hline & & 57.36 & 10.33 & & \\
\hline & \multirow{2}{*}{$\mathrm{L}$} & 47.69 & 13.03 & \multirow{2}{*}{-0.87} & \multirow{2}{*}{0.41} \\
\hline & & 52.35 & 14.06 & & \\
\hline \multirow{4}{*}{ LD } & \multirow{2}{*}{$\mathrm{R}$} & 54.72 & 12.20 & \multirow{2}{*}{0.88} & \multirow{2}{*}{0.40} \\
\hline & & 50.63 & 8.17 & & \\
\hline & \multirow{2}{*}{$\mathrm{L}$} & 52.74 & 8.31 & \multirow{2}{*}{-1.25} & \multirow{2}{*}{0.2} \\
\hline & & 55.40 & 10.56 & & \\
\hline \multirow{4}{*}{ RA } & \multirow{2}{*}{$\mathrm{R}$} & 54.29 & 7.83 & \multirow{2}{*}{0.25} & \multirow{2}{*}{0.81} \\
\hline & & 53.28 & 6.35 & & \\
\hline & \multirow{2}{*}{$\mathrm{L}$} & 51.38 & 13.86 & 052 & 061 \\
\hline & & 47.34 & 11.88 & 0.02 & 0.01 \\
\hline & $\mathrm{P}$ & 52.30 & 9.70 & 063 & 0.54 \\
\hline TR & $\mathrm{K}$ & 49.99 & 12.05 & & \\
\hline ID & I & 44.47 & 11.30 & 113 & בר 0 \\
\hline & $L_{2}$ & 52.79 & 15.60 & -1.13 & 0.29 \\
\hline
\end{tabular}




\section{3) 구간 3(Section 3)}

구간 3에서의 스위핑 당기기와 밀기 간 근 동원 평균의 유의한 차이 검증 결과, 우측 삼각근에서 유의한 차이를 보 였다 $(\mathrm{t}=-2.48, \mathrm{p}<.01)$. 평균 비교 결과는 당기기 시 $41.18 \% \mathrm{RVC}$, 밀기 시 $56.06 \% \mathrm{RVC}$ 를 나타내 밀기 시 더 큰 근 활성도를 나타냈다(Table 8).

Table 8. Mean comparison of EMG during sweeping pulling and pushing (section 3)

\begin{tabular}{|c|c|c|c|c|c|}
\hline \multicolumn{2}{|c|}{ Muscles(EMG) } & $\mathrm{M}$ & SD & $t$ & $p$ \\
\hline \multirow{4}{*}{$\mathrm{DE}$} & \multirow{2}{*}{$\mathrm{R}$} & 41.18 & 9.49 & \multirow{2}{*}{$-2.48^{* *}$} & \multirow{2}{*}{0.03} \\
\hline & & 56.06 & 17.66 & & \\
\hline & \multirow{2}{*}{$\mathrm{L}$} & 86.63 & 120.24 & \multirow{2}{*}{1.22} & \multirow{2}{*}{0.25} \\
\hline & & 37.71 & 16.19 & & \\
\hline \multirow{4}{*}{ PM } & \multirow{2}{*}{$\mathrm{R}$} & 57.99 & 14.82 & \multirow{2}{*}{1.17} & \multirow{2}{*}{0.27} \\
\hline & & 49.23 & 10.25 & & \\
\hline & \multirow{2}{*}{$\mathrm{L}$} & 45.22 & 15.00 & \multirow{2}{*}{-1.19} & \multirow{2}{*}{0.26} \\
\hline & & 61.90 & 32.26 & & \\
\hline \multirow{4}{*}{$\mathrm{BB}$} & \multirow{2}{*}{$\mathrm{R}$} & 70.02 & 38.31 & \multirow{2}{*}{1.47} & \multirow{2}{*}{0.17} \\
\hline & & 54.72 & 15.81 & & \\
\hline & \multirow{2}{*}{$\mathrm{L}$} & 63.64 & 64.77 & \multirow{2}{*}{0.78} & \multirow{2}{*}{0.46} \\
\hline & & 51.46 & 20.34 & & \\
\hline \multirow{4}{*}{ LD } & \multirow{2}{*}{$\mathrm{R}$} & 54.66 & 8.92 & \multirow{2}{*}{0.67} & \multirow{2}{*}{0.52} \\
\hline & & 52.72 & 8.98 & & \\
\hline & \multirow{2}{*}{$\mathrm{L}$} & 53.76 & 9.54 & \multirow{2}{*}{-0.50} & \multirow{2}{*}{0.63} \\
\hline & & 57.20 & 22.58 & & \\
\hline \multirow{4}{*}{ RA } & \multirow{2}{*}{$\mathrm{R}$} & 55.12 & 7.36 & \multirow{2}{*}{-0.10} & \multirow{2}{*}{0.92} \\
\hline & & 55.35 & 4.46 & & \\
\hline & \multirow{2}{*}{$\mathrm{L}$} & 45.90 & 11.46 & 174 & 12 \\
\hline & & 61.49 & 22.55 & $-1 . / 4$ & 0.12 \\
\hline & $\mathrm{R}$ & 54.34 & 17.37 & 114 & 8כ0 \\
\hline $\mathrm{TR}$ & $\mathrm{n}$ & 61.68 & 33.25 & -1.14 & 0.20 \\
\hline ID & & 63.01 & 62.88 & & 040 \\
\hline & $\mathrm{L}$ & 48.52 & 17.18 & 0.88 & 0.40 \\
\hline
\end{tabular}

\section{스톤의 멈춘 위치 확인}

같은 힘과 방향으로 던져진 스톤들을 각 구간별 스위핑을 통해 이루어진 스톤의 멈춘 위치를 확인하여 스톤간의 거리 를 길이(진행거리)와 너비(진행방향)를 각각 체크하여 기록 한 결과 〈Table 9〉과 같다.
Table 9. Record

\begin{tabular}{cccc}
\hline \hline Subjects & $\begin{array}{c}\text { Section 1 } \\
\text { Turn-Line-Weight }\end{array}$ & $\begin{array}{c}\text { Section 2 } \\
\text { Turn-Line-Weight }\end{array}$ & $\begin{array}{c}\text { Section 3 } \\
\text { Turn-Line-Weight }\end{array}$ \\
\hline sub.1 & $-0.5 / 3$ & $\mathrm{C} / 3$ & $-0.5 / 2$ \\
\hline sub.2 & $0.5 / 3$ & $\mathrm{C} / 2.5$ & $\mathrm{C} / 2$ \\
\hline sub.3 & $0.5 / 1.5$ & $\mathrm{C} / 2$ & $-0.5 / 3$ \\
\hline sub.4 & $0.5 / 3.5$ & $\mathrm{C} / 3$ & $-0.5 / 3$ \\
\hline sub.5 & $\mathrm{C} / 3$ & $\mathrm{C} / 3.5$ & $\mathrm{C} / 3.5$ \\
\hline sub.6 & $-0.5 / 3$ & $\mathrm{C} / 3.5$ & $-0.5 / 2$ \\
\hline sub.7 & $\mathrm{C} / 2$ & $\mathrm{C} / 2$ & $0.5 / 2$ \\
\hline sub.8 & $0.5 / 2.5$ & $0.5 / 3$ & $\mathrm{C} / 2$ \\
\hline sub.9 & $\mathrm{C} / 2.5$ & $0.5 / 3$ & $\mathrm{C} / 2.5$ \\
\hline sub.10 & $0.5 / 3$ & $\mathrm{C} / 2$ & $0.5 / 1.5$ \\
\hline \hline
\end{tabular}

각 구간별 스위핑 동작 시 스톤의 멈춘 위치 확인을 명확 하게 하기 위해 모든 턴은 아웃 턴으로 정하여서 투구하였고 스톤의 서는 위치가 센터를 기준으로 센터를 넘어가면 플러 스(+)로 센터를 넘어가지 않으면 마이너스(-)로 하였으며 센터에 섰을 때는 센터(Center, C)로 기록 하였다. 각 구간 별 스톤의 멈춘 위치를 확인한 결과 1 구간에서는 라인은 모 두 $-0.5 \sim 0.5$ 사이로 거의 센터라인 쪽으로 위치해 있는 것 을 알 수 있고 웨이트는 2 3사이를 크게 벗어나지 않은 것 으로 확인된다. 2 구간 역시 대부분의 스톤이 센터라인 쪽으 로 멈췄고 웨이트는 2 3.5사이의 구간에 모두 모였다. 마지 막 3구간 스톤의 멈춘 라인도 센터라인에서 크게 벗어나지 않은 것 나타났으며 웨이트는 1구간과 거의 비슷하게 2 3 사이를 크게 벗어나지 않았다.

또한 기준 웨이트는 투구하였을 때 스위핑 도움 없이 C-3에 가서 멈추는 것으로 하였다. 그리고 30분 간격으로 C-3의 위치에 서는 기준 웨이트를 측정한 결과 기준 웨이트 의 변화는 백라인-호그라인까지 4.05초 - 3.90초 - 3.80초 -3.70 초 -3.60 초로 각각 나타났다.

\section{논 의}

스위핑의 당기는 힘을 볼 때 스톤의 속도가 빠른 1,2 구 간에서는 광배근과 복직근의 큰 근육들이 사용되는 반면 속 도가 느려지는 3 구간에서는 삼각근과 상완이두근과 같은 
주로 팔 근육이 현격히 많이 사용되는 패턴이 나타났다. 이 는 속도가 약해지는 스톤의 웨이트를 보다 더 많이 이동시키 기 위해 체중을 많이 싫어 스위핑 하기 때문에 이러한 결과 가 나타난 것으로 사료된다. 이를 뒷받침하는 연구로 5년의 컬링 경력자와 초보자의 스위핑 시 수직 하중력을 비교한 연 구 결과, 수직 하중력 및 컬링 브러쉬를 옆으로 움직여 가는 힘 값이 경력자에게서 더 크게 나타났다(Hitoshi et al, 2012). 또한, 3구간으로 갈수록 스톤의 이동을 더 시키는 것과 스톤을 목표하는 지점으로 이동시킬 수 있도록 스톤을 굴곡 시키는 것이 스위핑이 무엇보다 중요한데 이때 수직 하 중력이 스톤의 굴곡을 만드는데 매우 중요하다고 하였다 (Hitoshi et al, 2008).

스위핑 구간별 밀기 시 1,2 구간에서는 대부분 오른쪽 팔 과 가슴에 힘이 들어가는 것으로 보아 체중을 싣고 있는 왼 쪽 부분은 광배근으로 버티면서 오른쪽 팔과 가슴으로 브러 쉬를 움직이는 것을 확인할 수 있었고, 3 구간 밀기 동작에서 는 상완이두근의 근육보다 몸통의 근육을 많이 사용하는 패 턴이 나타났다.

1,2 구간은 선수들이 체력이 있는 상태에서 상지의 등 그 리고 몸통에 있는 근육을 골고루 활용하여 스위핑이 이루어 지다가 3 구간에서 체력이 떨어지면서 브러쉬에 체중을 실 어 스위핑을 하기 때문에 브러쉬에 밀착되어 균형을 잡아주 기 위해 왼쪽 삼각근과 상지의 근육이 많이 동원되는 것으로 사료된다. 이러한 결과와 관련하여 국가대표 컬링 선수들의 컬링 브러쉬 잡기 위치에 관한 연구에서 여자 선수들은 브러 쉬 그립을 잡을 때는 짧게 잡고, 비교적 상지의 근력이 좋은 남자 선수들은 길게 잡는다고 하였다(Kim et al., 2018). 이는 브러쉬를 누르면서 앞뒤로 미는 동작에서 삼각근과 상 완이두근의 역할이 매우 중요한데 위와 같은 결과를 근거로 가장 격렬한 스위핑을 해야 하는 3 구간에서 이러한 패턴이 나타났다고 판단된다.

스위핑 당기기와 밀기 시 근 동원 양상의 차이를 알아본 결과 $1,2,3$ 구간 모두 밀기 시 우측 삼각근의 동원율이 당 기기 시 보다 더 크게 나타남을 알 수 있었다. 이는 스위핑 시 수직 하중력을 만들기 위해서는 스위핑 브룸을 밑으로 강 하게 누르면서 스위핑을 해야하는데 이때 삼각근의 동원이 매우 필요하다. 이와 동시에 1 구간에서 당기기 시 상완삼두 근의 근 동원율이 밀기 시보다 더 크게 나타났는데 스톤의 투사 직후 스위핑의 속도를 올리기 위해 상완삼두근을 이용 하여 더 빠른 동작을 만들기 위해 나타난 결과이다. 따라서
효과적인 스위핑을 하기 위해서는 수직 하중력의 생성과 스 위핑 속도를 높게 하는 것이 매우 중요하다는 선행연구와 일 치하는 결과라고 볼 수 있다(Kim et al., 2021).

각 구간별 스톤의 멈춘 위치 결과를 보면 모든 구간에서 거의 센터라인에 멈추는 것을 확인할 수 있었고, 기준 웨이 트 투구 시 백라인-호그라인 가장 긴 시간과 짧은 시간의 차 이가 0.45 초 차이가 나타났는데 이러한 현상은 타임을 측정 하는데 있어 레이저 방식이 아닌 선수가 수동으로 측정하였 기 때문에 나타나는 오차율과 시간이 지날수록 얼음상태가 나빠져서 처음 투구를 할 때의 스톤의 웨이트와 마지막 투구 할 때의 스톤의 웨이트가 차이가 나타난 것으로 사료된다. 이는 스위핑의 효과를 측정하는 데에 있어서 가장 큰 변인으 로 꼽을 수 있다.

\section{결론 및 제언}

본 연구는 스톤의 움직임이 스위핑을 통하여 컨트롤 될 때 어떤 타이밍에 얼마만큼의 스톤의 궤적을 만드는지 또한 각 호그 투 호그 구간의 스위핑 시 근 활성도는 어떤 변화가 있는지를 찾아 스위핑에 필요한 훈련에 기초적 자료를 제공 하는데 목적이 있었다. 연구의 목적을 달성하기 위해 U고등 학교 및 중학교 남자컬링선수 10 명을 대상으로 근전도 분석 을 실시하였으며, 연구결과 다음과 같은 결론을 얻었다. 첫 째. 컬링 스위핑 당기기 시 구간별 근 활성도에서 1 구간에서 왼쪽 광배근(57.7\%), 오른쪽 복직근(55.3\%), 오른쪽 상완 삼두근(53.7\%)의 비율 순으로 많이 사용되었으며, 2 구간에 서는 오른쪽 상완이두근(57\%), 오른쪽 광배근(54.7\%), 오 른쪽 복직근(54.3\%)의 비율 순으로 나타났다. 마지막 3구 간에서는 왼쪽 삼각근(86.6\%), 오른쪽 상완이두근(70\%), 왼쪽 상완이두근(63.6\%)의 비율 순으로 많이 사용되는 것 으로 나타났다.

둘째, 컬링 스위핑 밀기 시 구간별 근 활성도에서 1 구간 에서는 오른쪽 상완이두근(57.5\%), 오른쪽 대흥근(56.6\%), 왼쪽 상완이두근(56.5\%)의 비율 순으로 많이 사용되었으 며, 2 구간에서는 오른쪽 상완이두근(57.4\%), 왼쪽 광배근 (55.4\%), 오른쪽 대흉근(54.8\%)의 비율 순으로 나타났다. 마지막 3 구간에서는 오른쪽 상완삼두근(61.7\%), 왼쪽 복직 근(61.5\%), 왼쪽 광배근(57.2\%)순으로 많이 사용된 것으로 나타났다. 
셋째, 컬링 스위핑 당기기 시 근동원순서는 1 구간에서 왼 쪽 광배근 > 오른쪽 상완삼두근 > 오른쪽 복직근 순으로 나 타났으며, 2구간에서는 오른쪽 상완이두근 > 오른쪽 광배근 $>$ 오른쪽 복직근 순으로, 마지막 3구간에서는 왼쪽 삼각근> 오른쪽 상완이두근 > 왼쪽 상완이두근 순으로 나타났다.

넷째, 컬링 스위핑 밀기 시 근동원순서는 1 구간에서 오른 쪽 상완이두근 > 오른쪽 대흉근 > 왼쪽 상완이두근 순으로 나타났으며, 2 구간에서는 오른쪽 상완이두근 > 왼쪽 광배근 $>$ 오른쪽 대흉근 순으로, 마지막 3구간에서는 왼쪽 대흉근> 오른쪽 상완삼두근 > 왼쪽 복직근 순으로 나타났다.

다섯째, 스위핑 시 당기기와 밀기 간 근 동원율에서는 1 , 2,3 구간에서는 우측 삼각근이 밀기 시 높게 나타났고, 1 구 간에서는 당기기시 상완삼두근이 높게 나타났다.

여섯째, 각 구간별 스톤의 멈춘 위치를 확인한 결과 1 구 간에서는 라인은 모두 $-0.5 \sim 0.5$ 사이로 거의 센터라인 쪽으 로 위치해 있는 것을 알 수 있고 웨이트는 2 3사이를 크게 벗어나지 않은 것으로 나타났다. 2구간 역시 대부분의 스톤 이 센터라인 쪽으로 멈췼고 웨이트는 2 3.5사이의 구간에 모두 모였다. 마지막 3구간 스톤의 멈춘 라인도 센터라인에 서 크게 벗어나지 않은 것 나타났으며 웨이트는 1 구간과 거 의 비슷하게 2 3사이를 크게 벗어나지 않았다. 그리고 30 분 간격으로 C-3의 위치에 서는 기준 웨이트를 측정한 결과 기준 웨이트의 변화는 백라인-호그라인까지 4.05 초 - 3.90 초 -3.80 초 -3.70 초 -3.60 초로 각각 나타났다.

본 연구를 통해 스톤의 속도가 빠른 1,2 구간과 스톤의 속 도가 느린 3 구간의 근 동원양상이 다르게 나타나는 것으로 스톤이 느리게 움직일 때 힘을 많이 써 힘이 남은 다른 근육 을 이용해 좀 더 스위핑에 집중하는 것을 확인할 수 있으며, 컬링의 스위핑 동작은 대부분 상지의 여러 근육들이 골고루 쓰여 지는 운동으로 상체근육의 발달에 적합한 종목이라 것 을 검증할 수 있다. 하지만 스톤의 구간별 스위핑 효과는 대 기온습도의 변화, 아이스 온도의 변화, 페블의 온도-크기-개 수, 스톤의 엣지 상태-반발력 등과 같은 다양한 변수에 따라 스톤이 움직이는 크기 각도 등이 변하는 변수가 많은 운동 종 목으로 선수들의 많은 경험에 의하여 이러한 변수들에 대해 대처할 수가 있고 훈련이 필요할 것으로 판단된다.

\section{참고문헌}

Bradley, J. L. (2009). The sports science of curling: a practical review. Journal of sports science \& medicine, 8(4), 495.

B A Marmo, I S Farrow, M-P Buckingham and J R Blackford. (2006). Frictional heat generated by sweeping in curling and its effect on ice friction. Proceedings of the Institution of Mechanical Engineers, Part L: Journal of Materials Design and Applications., 220, 189-197.

Hitoshi Yanagi, Katsumi Miyakoshi, Yasushi Nakajima, Noriyuki Yamamoto, and Tadao Isaka (2008). Measurment of forces exerted during sweeping in curling, ISBS Conference 2008, July 14-18

Hitoshi Yanagi, Katsumi Miyakoshi, Masatoshi Fukuoka and Noriyuki Yamamoto. (2012). Development of curling brush for measuring force exerted during sweeping, 30th Annual Conference of Biomechanics in Sports., 354-356.

Kim. J. D., Kim. H. K., \& Kim. M. Y. (2004). Motion Analysis On the nobackswing Delivery of Curling. The Korean Society of Sports Science, 13(2), 857-863.

Kim. Y. S., \& Cho, K. K. (2005). The Kinematic Analysis of Delivery Motion in Curling Game. Korean Journal of Physical Education, 44(1), 331-340.

Kim. H. K., \& Yoo. K. S. (2006). A Study of Plantar Pressure Distribution in the Propulsive and Sliding Phase during Curling Delivery. Korean Journal of Physical Education, 45(1), 725-734.

Kim. T. W., Moon. Y. J., Song. J. H., Lee. S. C., Kil. S. K., \& Moon. J. H. (2014). Comparative Analysis of the Change CoM Displacement, CoM Velocity and Foot-Pressure in Draw and Takeout Curling Skills. Korean Journal of Sport Science, 25(2), 268-278.

Kim. T. W., Lee. S. C., Kil. S. K., Lee. K. H., \& Choi. S. H. (2018). The Effects of Curling Brush Grab Types on Sweeping Techniques. Korean Journal of Physical Education, 57(6), 285-292.

Kim. H. K., \& Yoo. K. S. (2006). A Study of Plantar Pressure Distribution in the Propulsive and Sliding Phase during Curling Delivery. Korean Journal of Physical Education, 45(1), 725-734.

Kim, T. W., Lee, S. C., Kil, S. K., Choi, S. H., \& Song, Y. 
G. (2021). A Case Study on Curling Stone and Sweeping Effect According to Sweeping Conditions. International. Journal of Environmental Research and Public Health, 18(2), 833.

Kivi D. \& Auld T. (2012). Directional Accuracy of The Delivery in Competitive Curlers. Journal of Biomechanics, 30th Annual Conference of Biomechanics in Sports(164), 350-353.

Lee. H. J. (2005). AKinematic Analysis on Lower Extremity Joint during Curling Delivery Movement. unpublished master's thesis. Sungshin Women's University.

Lee. S. C., Kim, T. W., Kil. S. K., \& Choi. S. H. (2005). Development of a force measurement device for curling sweeping with load cells. Journal of the Korea Convergence Society, 8(11), 49-56.

M-P Buckingham, B A Marmo and J R Blackford. (2006).
Design and use of an instrumented curling brush. Proceedings of the Institution of Mechanical Engineers, Part L: Journal of Materials Design and Applications., 220, 199-205.

Yoo. K. S. (2007). A Study on ROM of lower limbs and loading response for control ability of sliding in Curling delivery. The Korean Society of Sports Science, 16(1), 609-621.

Yoo. K. S. (2009). Influence of the Speed Control on Regulation of Posture and Factor of Loading Foot Pressure following Inverse Pendulum Model in Curling. Journal of Sport and Leisure Studies, 36, 737-746.

Yoo, K. S., Kim, H. K. and Park, J. H.(2012). A Biomechanical Assessment of the Sliding Motion of Curling Delivery in Elite and Subelite Curlers. Journal of Applied Biomechanics, 28, 694-700.

\title{
컬링 호그 투 호그 각 구간 스위핑 시 근 동원 양상 및 스톤의 정지 위치 분석
}

\author{
권영일 ${ }^{1}$, 김태완 $^{2}$, 최상협 $^{3}$ \\ ${ }^{1}$ 의정부시설관리공단 시설관리인 \\ 2한국스포츠정책과학원, 책임연구위원 \\ ${ }^{3}$ 제주스포츠과학센터, 선임연구원
}

[목적] 컬링에서 구간별 스위핑 동작의 차이가 스톤의 이동 궤적과 근 활성에 어떤 차이를 보이는지 확인하 여 컬링 스위핑 훈련에 기초적인 자료를 제공하는데 본 연구의 목적이 있다. 〔방법] 각 구간별 스위핑을 시 스톤의 멈춘 위치를 확인하여 스톤 간의 길이(진행거리)와 너비(진행방향)를 확인하고, 이를 기록하기 위해 기 준표를 통해와 기록 작성표에 기록하였다. 또한, 총 12 부위의 근육에 $\mathrm{EMG}$ 를 부착하고 구간 시작과 끝나는 시점까지 각 구간 당 20 번 씩 총 60 번 스위핑을 하게 하였다. 스위핑을 하는 대상자가 세 구간 모두 같은 조건 으로 최대한 스위핑을 할 수 있도록 요구하였다. [결과] 연구결과, 스톤의 속도가 빠른 1,2 구간과 스톤의 속도 가 느린 3 구간의 근 동원양상이 다르게 나타났는데, 스톤이 느리게 움직일 때 힘을 많이 써 힘이 남은 다른 근육을 이용해 좀 더 스위핑에 집중하는 것을 확인할 수 있었으며, 컬링의 스위핑 동작은 대부분 상지의 여러 근육들이 골고루 사용되는 동작으로 상체근육의 발달에 적합한 종목이라는 것을 검증할 수 있었다. 또한 밀기 시 우측 삼각근, 당기기 시 우측 상완삼두근의 근동원율이 높다는 것을 알 수 있었다. [결론] 스톤의 구간별 스위핑 효과는 대기온습도의 변화, 아이스온도의 변화, 패블의 온도-크기-개수, 스톤의 엣지 상태-반발력 등에 따라 스톤이 움직이는 크기 각도 등이 변하는 변수가 많은 운동 종목으로 선수들의 많은 경험에 의하여 이러한 변수들에 대해 대처할 수가 있고 훈련이 필요할 것으로 판단된다.

주요어: 스위핑, 근전도, 컬링 스톤, 호그 투 호그 